\title{
An Experimental Study on Flipped Classrooms of English Pronunciation
}

\author{
Lei Zhang \\ School of Foreign Language \\ Dalian Neusoft University of Information \\ Dalian, China
}

\begin{abstract}
This study analyzed the teaching effectiveness in three different flipped classrooms of self-developed English Pronunciation courses. Through a quantitative analysis of multiple data sources, the researcher found that the scores of all the three flipped classrooms were significantly improved. The teachers' role and participation have a great impact on students' performance in different flipped classrooms. The class where teacher performs as organizers provide more opportunities for team members to communicate and cooperate with each other, which entails positive feedbacks.
\end{abstract}

Keywords-Flipped Classroom; English Pronunciation; Teaching Effectiveness; Students' Perceptions

\section{INTRODUCTION}

In our times, the increasing demand for global competence and international communication makes acquiring proficiency in a second language more prominent and this proficiency should cover not only vocabulary and grammar, but good pronunciation as well [1]. Therefore, pronunciation instruction is of great importance for successful oral communication since it is an essential ingredient of the communicative competence. There have been numerous studies on the effectiveness of pronunciation instruction, and the central issue of pronunciation instruction is how to teach effectively. [2]

Along with the development of the instructional approaches, traditional teaching method has been challenged during the recent years, and new teaching techniques have been introduced in teaching. Flipped classroom is one of these new teaching approaches. A typical flipped classroom approach provides students with online video lectures prior to in-class studies so that students are ready to participate in more interactive and higher-order activities such as problem solving, discussions, and debates. [3] Some scholars have conducted a series of empirical studies to flipped classes. Most of the studies abroad have a positive attitude towards the teaching effect of flipped classes. Some scholars argued that flipped class can create a flexible and diverse learning environment for students, enhance student's interaction and motivation, and teachers in turn are able to commit more time to monitoring students' performance and providing instant feedback to a student. [4] However, Strayer reported that students perceived a significantly lower level of support to facilitate student conduct during flipped events, warning that this perceived lack of support might lead to lower engagement. It is questionable whether the flipped classroom can significantly improve students' academic performance. [5] Kim studied three different flipped classes of the University of Southern California and put forward 9 principles in flipping classroom designing from the perspective of learners. [6]

Flipped classroom, a newly emerging instruction mode, with its own advantages and characteristics, seems to provide a new way in pronunciation instruction. Therefore, an experimental study of flipped classrooms on pronunciation is conducted to find out whether the flipped classroom approach is superior to a traditional one and how can the teaching effectiveness of this approach be maximized.

\section{RESEARCH DESIGN}

Born out of a desire to meet the needs of freshmen English majors who seek improvement in English pronunciation with the convenience and efficiency of online instruction, the flipped class started in pursuit of providing efficient learning tools by which students can be more engaged and confident about their learning. Over the period of fall 2017 semester, three freshmen classes of English majors participated in the study. The three participating teachers designed their flipped classroom in accordance with their personal preferences and teaching experiences, which resulted in different forms of flipped classes. All classes were exposed to the content of the course before class according to the principles of designing flipped classes presented by M.K. Kim in the study of the University of southern Canada. [6] 12 short self-developed videos about "English Pronunciation" integrating the most important segmental and supra-segmental were employed as learning materials. The forms of different flipped classrooms were listed as follows: 
TABLE I. Different Teaching Modes of Three Flipped ClassRooms

\begin{tabular}{|c|l|l|l|}
\hline & \multicolumn{1}{|c|}{ Class A } & \multicolumn{1}{|c|}{ Class B } & \multicolumn{1}{c|}{ Class C } \\
\hline $\begin{array}{c}\text { Flipping } \\
\text { Approach }\end{array}$ & $\begin{array}{l}\text { Flipping in-class } \\
\text { lectures and individual } \\
\text { practice }\end{array}$ & $\begin{array}{l}\text { Flipping in-class lectures } \\
\text { and group work }\end{array}$ & $\begin{array}{l}\text { Flipping the role of } \\
\text { teacher and student }\end{array}$ \\
\hline $\begin{array}{c}\text { In-Class } \\
\text { Activities }\end{array}$ & $\begin{array}{l}\text { Individual practice; } \\
\text { teacher supervision and } \\
\text { evaluation }\end{array}$ & $\begin{array}{l}\text { Group } \\
\text { competition, discussion } \\
\text { and evaluation }\end{array}$ & $\begin{array}{l}\text { Peer learning without the } \\
\text { presence of a teacher; } \\
\text { recording }\end{array}$ \\
\hline $\begin{array}{l}\text { Out-of-Class } \\
\text { Activities }\end{array}$ & $\begin{array}{l}\text { Video lecture; } \\
\text { reflective journal }\end{array}$ & $\begin{array}{l}\text { video lecture; reflective } \\
\text { journal }\end{array}$ & $\begin{array}{l}\text { video lecture; reflective } \\
\text { journal; teacher's } \\
\text { comments on peer } \\
\text { learning }\end{array}$ \\
\hline Teacher's Role & Inspector & Organizer & Observer \\
\hline
\end{tabular}

As can be seen from table 1 , the mode of flipping classroom varies from one to another in accordance with teachers' role. In Class A, a student practiced their pronunciation independently and individually following the short videos, while the teacher performed as a tutor and inspector. In Class $\mathrm{B}$, students conducted inter-group competitions, group discussions, peer teaching and other activities, while the teachers provided facilitation and acted as organizers. In Class $\mathrm{C}$, the role of the students and teachers flipped, students did peer learning by themselves and were required to record their learning processes and submit it to the teacher for evaluation after class. The teacher, as the observer of the classroom activities, participated the least in the classroom activities.
At the beginning and the end of the semester, the students of three classes received pre-and post-test of their pronunciation respectively. The pronunciation test designed by author's research team was divided into two parts, the receptive pronunciation test (40 points) and the output pronunciation test (60 points). The test included consonants, vowels, word stress, sentence stress, rhythm pattern and intonation pattern. A oneto-one output pronunciation test with 4-5 minutes per person was followed, including phonetics reading, words, sentence reading, poetry reading and text reading. The output test was scored by two raters, and the average score was finally taken. Audio output is saved by cool Edit 2.0.

TABLE II. ONE-WAY ANOVA ANALYSIS OF THREE FLIPPED CLASSROOMS

\begin{tabular}{|c|c|c|c|c|c|c|c|}
\hline Class & Time & Average & $\begin{array}{l}\text { Standard } \\
\text { Deviation }\end{array}$ & $\begin{array}{l}\text { Mean } \\
\text { Difference } \\
\quad(\mathrm{MD}) \\
\end{array}$ & $\begin{array}{c}\text { Degrees of } \\
\text { Freedom } \\
\text { (DF) }\end{array}$ & $\mathrm{T}$ & $\begin{array}{l}\mathrm{P} \text { (two } \\
\text { tails ) }\end{array}$ \\
\hline \multirow{2}{*}{ Class A } & pre & 64.8 & 6.03 & \multirow{2}{*}{-14.33} & \multirow{2}{*}{30} & \multirow{2}{*}{-8.208} & \multirow{2}{*}{0.000} \\
\hline & post & 79.1 & 6.47 & & & & \\
\hline \multirow{2}{*}{ Class B } & pre & 62.8 & 6.05 & \multirow{2}{*}{-16.09} & \multirow{2}{*}{28} & \multirow{2}{*}{-9.023} & \multirow{2}{*}{0.000} \\
\hline & post & 78.9 & 7.17 & & & & \\
\hline \multirow{2}{*}{ Class C } & pre & 65.6 & 11.38 & \multirow{2}{*}{-6.98} & \multirow{2}{*}{29} & \multirow{2}{*}{-3.189} & \multirow{2}{*}{0.003} \\
\hline & post & 72.6 & 13.62 & & & & \\
\hline
\end{tabular}

Table II indicated that the pre and post-test values were significantly different in all three classes, which proved that the scores of the three-class pronunciation test dramatically improved compared with those in the previous period, which echoed the study of Tune et al. [7] Inter-group ANOVA analysis indicated that there was no significant difference of three classes in pre-test. [ $F(2,87)=4.63, \mathrm{P}<0.05]$ On the contrary, scores of class $\mathrm{A}$ and $\mathrm{B}$ were significantly higher than Class $C$ in the post test. ( $M D=6.81, M D=6.99)$, while the scores of Class A did not differ significantly from Class B. 
TABLE III. ONE-WAy ANOVA ANALysis BETWEEN ThreE FLIPPED CLASSROOMS

\begin{tabular}{|c|c|c|c|c|c|}
\hline & $\begin{array}{l}\text { Class A } \\
(n=32)\end{array}$ & $\begin{array}{l}\text { Class B } \\
(n=30)\end{array}$ & $\begin{array}{l}\text { Class C } \\
(n=31)\end{array}$ & & Games-Howell \\
\hline Scores & $\begin{array}{ll}\text { M } & \text { SD } \\
79.1 & 6.47\end{array}$ & $\begin{array}{ll}\text { M } & \text { SD } \\
78.9 & 7.17\end{array}$ & $\begin{array}{ll}\text { M } & \text { SD } \\
72.1 & 13.62\end{array}$ & $5,862 *$ & $\begin{array}{l}\text { Class } \mathrm{A}>\text { Class } \mathrm{C} \\
\text { Class } \mathrm{B}>\text { Class } \mathrm{C}\end{array}$ \\
\hline
\end{tabular}

Table III indicated that different flipping classroom models had different effects on the students’ performance.

\section{QUANTITATIVE ANALYSIS}

A questionnaire was distributed to the students to give a sight into students' satisfaction about flipped classrooms. The satisfaction survey was conducted from the perspectives of learner, teacher, curriculum and environment. Learners' perspective refers to the students' learning motivation, interest and learning strategy; teacher's perspective is regarded as the teachers' instruction to the students and the communication with the students; curriculum perspective denotes the content, form and activities of the class; environment perspective is deemed to be the interaction, cooperation, communication and network quality. The questionnaire contains 15 questions, with 4 learning questions, 4 teacher questions about teacher, 4 curriculum questions, and 3 environment questions. The quantitative data were analyzed by the Likert five level scale. (1= very satisfied; 2 = unsatisfied; 3 = general; 4 = satisfied; 5 $=$ very satisfied). A total of 82 students out of 93 students participated in the questionnaire survey, and the questionnaire response rate is $88 \%$.

TABLE IV. STUDENTS’ SATISFACTION SURVEY RESUltS

\begin{tabular}{|ccccccccccc|}
\hline & Number of Response & \multicolumn{3}{c|}{ Mean } & \multicolumn{3}{c|}{ Standard Deviation } \\
\hline & A & B & C & A & B & C & \multicolumn{3}{c|}{ A } & C \\
\hline Learner & 28 & 29 & 25 & 3.18 & 3.05 & 3.09 & 0.44 & 0.35 & 0.46 \\
\hline Teacher & 28 & 28 & 25 & 3.33 & 3.53 & 3.43 & 0.81 & 0.65 & 0.43 \\
\hline Curriculum & 28 & 29 & 25 & 4.18 & 4.32 & 3.67 & 0.67 & 0.56 & 0.74 \\
\hline Environment & 28 & 29 & 24 & 2.80 & 3.56 & 2.78 & 0.53 & 0.46 & 0.71 \\
\hline
\end{tabular}

As can be seen from the Table 4, curriculum satisfaction was at the top, indicating that students were most satisfied with the class activities and teaching materials. Teacher satisfaction ranked second, which denoted that the students were generally satisfied with the teachers. However, teacher satisfaction was relatively lower in Class $\mathrm{C}$, where teacher acted as the observer. This result echoed the study of Strayer [5], which stated that the lack of teachers' support in the flipped classroom would led to learners' lack of motivation. Learners perceived that they were not performing very well in these classes, however, they favored the class B where teacher performed as the organizer.

\section{CONCLUSION}

First, the results of this study indicated the students' pronunciation improved significantly through flipped class instruction. The diversified in-class activities strengthen students' mastery of the basic knowledge in pronunciation, enhance their interest and motivation in learning, and promote the interactive communication.

Second, significant differences in three classrooms indicate different teaching effect of three classrooms. The potential value of student-centered learning environment facilitates students to do higher-order tasks and manage their own learning, nonetheless, creating such environments remains a challenge. Teachers performing their roles as organizer to achieve an effective balance between lectures and class activities are most favored by the students. The traditional classroom can be turned into a student-centered and democratic learning place when the teacher performs as the observer. However, this "seemingly beautiful' model of flipping classroom teaching is not very popular among students, especially in classrooms that emphasize basic knowledge and require immediate feedback.

Third, clearly defined guidance and necessary scaffolding should be provided for the students in the flipped classroom. With well-defined instructions, teachers can facilitate students' in class activities to reinforce the basic knowledge. Students should be informed of more specific goals while they are doing group discussions or teamwork.

In spite of all the findings from this study, there are still a few limitations. The number of the students participating in the study is small and data obtained are not sufficient. The size of the class is small, there is still the need to explore the implementation of the flipped class in larger size classes. Qualitative analysis should be conducted in the future to analyze the perceptions and changes in students' motivation and emotion in depth. 


\section{REFERENCES}

[1] Lord, G. Podcasting communities and second language pronunciation. Foreign Language Annals, 41, 2008, PP. 374-389.

[2] Hismanoglu, M. Current Perspectives on Pronunciation Learning and Teaching. Journal of Language and Linguistic Studies, 2(1). 2006, PP.89-96.

[3] Fulton, K. Upside Down and Inside Out: Flip Your Classroom to Improve Student Learning. Learning \& Leading with Technology, 39(8),2012, pp.12-17.
[4] Herreid, C., \& Schiller, N. Case studies and the flipped classroom. Journal of College Science Teaching, 42(5), 2013, pp.62.

[5] Strayer, J. F How learning in an inverted classroom influences cooperation, innovation and task orientation. Learning Environments Research, 15(2), 2012, PP.171-19.

[6] Kim, M. K., Kim, S. M., \& Khera, O. et al. The Experience of Three Flipped Classrooms in an Urban University: An Exploration of Design Principles [J]. The Internet and Higher Education, (22),2014,PP37-50.

[7] Tune,J.D,Sturel, M.\&Basil, D.P, Flipped classroom model improves graduate students performance in cardiovascular, respiratory, and renal physiology[J]. Advances in Physiology Education,2013,37(4). 